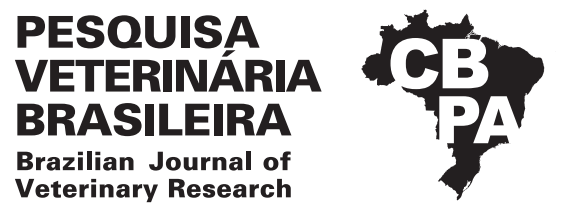

Pesq. Vet. Bras. 38(12):2190-2193, dezembro 2018 DOI: 10.1590/1678-5150-PVB-5532

Original Article

Animais de Produção/Livestock Diseases

ISSN 0100-736X (Print)

ISSN 1678-5150 (Online)

\title{
Insulin favors acute inflammatory reaction in alloxan-diabetic tilapia during infectious aerocystitis ${ }^{1}$
}

\author{
Ed Johnny R. Prado 2 , Marco Antonio A. Belo ${ }^{2,3 *}$, Alessandra C. Moraes², \\ Roberto Barbuio ${ }^{2}$, Elizabeth P. Foz ${ }^{3}$, Vanessa P. Faria ${ }^{3}$ and Fernanda A. Sebastião ${ }^{4}$
}

ABSTRACT.- Prado E.J.R., Belo M.A.A., Moraes A.C., Barbuio R., Foz E.P., Faria V.P. \& Sebastião F.A. 2018. Insulin favors acute inflammatory reaction in alloxan-diabetic tilapia during infectious aerocystitis. Pesquisa Veterinária Brasileira 38(12):2190-2193. Universidade Estadual Paulista Júlio de Mesquita Filho, Faculdade de Ciências Agrárias e Veterinárias, Campus de Jaboticabal, Via de acesso Prof. Paulo Donato Castellane s/n, Jaboticabal, SP 14884-900, Brazil. E-mail: maabelo@hotmail.com

In vertebrates, the inflammatory reaction is responsible for modulating the initial nonspecific defense until specific immunity is acquired. In this context, numerous studies in mammals have demonstrated the participation of insulin in the inflammatory response, favoring cell proliferation and the migratory capacity of endothelial cells, vascular smooth muscle cells and monocytes, as well as mediating the expression of pro-thrombotic and pro-fibrotic factors. However, little is known about the effect of this peptidic hormone on the inflammatory reaction in teleostean fish. In order to evaluate the participation of insulin in the acute inflammatory response of Nile tilapia, Oreochromis niloticus, during aerocystitis induced by Aeromonas hydrophila, and 48 aloxane-diabetic tilapia were used, constituting two groups: diabetics treated with insulin and diabetics without treatment. After six, 24, and 48 hours of inflammatory stimulation, tilapia were submitted to deep anesthesia for euthanasia and necropsy, and thus, obtaining exudate and harvesting of the swim bladder for analysis of the inflammatory reaction. Based on this premise, the present study demonstrated the participation of insulin in the acute inflammatory reaction of alloxan-diabetic tilapia by favors the cellular accumulation in the exudate, the proliferative effect of fibrous tissue and neovascularization in the inflamed site. Such findings reinforce the old hypothesis that insulin plays an important role in the innate immune response during acute inflammatory reaction, being an important pro-inflammatory hormone. However, Nile tilapia proved to be a promising experimental model for studies and advances in research involving diabetes mellitus.

INDEX TERMS: Insulin, acute inflammatory reaction, alloxan-diabetic, tilapia, aerocystitis, Oreochromis niloticus, cichlids, diabetes, peptidic hormones, inflammation, Aeromonas Hydrophila, clinics.

RESUMO.- [Insulina favorece a reação inflamatória aguda em tilápia do Nilo aloxano-diabéticas durante aerocistite infecciosa.] Em vertebrados, a reação inflamatória é responsável por modular a defesa inicial não-específica, até que imunidade

\footnotetext{
${ }^{1}$ Received February on 18, 2018.

Accepted for publication on June 19, 2018

${ }^{2}$ Faculdade de Ciências Agrárias e Veterinárias (FCAV), Universidade Estadual Paulista Júlio de Mesquita Filho (Unesp), Campus de Jaboticabal, Via de acesso Prof. Paulo Donato Castellane s/n, Jaboticabal, SP 14884-900 Brazil. *Corresponding author: maabelo@hotmail.com

${ }^{3}$ Universidade Brasil, Av. Hilário da Silva Passos 950, Descalvado, SP 13690-000, Brazil.

${ }^{4}$ Centro de Aquicultura, Universidade Estadual Paulista Júlio de Mesquita Filho (Unesp), Via de acesso Prof. Paulo Donato Castellane s/n, Jaboticabal, SP 14884-900.
}

específica seja adquirida. Neste contexto, inúmeros estudos em mamíferos têm demonstrado a participação da insulina sobre a resposta inflamatória, favorecendo a proliferação celular e a capacidade migratória das células endoteliais, células do músculo liso vascular e dos monócitos, além de mediar a expressão de fatores pró-trombótico e pró-fibrótico. Porém, pouco se conhece o efeito deste hormônio peptídico sobre a reação inflamatória em peixes teleósteos. Para avaliar a participação da insulina sobre a resposta inflamatória aguda em tilápias do Nilo, Oreochromis niloticus, na aerocistite induzida por Aeromonas hydrophila, foram utilizadas 48 tilápias aloxano-diabéticas, constituindo dois grupos: dos diabéticos tratados com insulina e diabéticos sem tratamento. Após, seis, 24 e 48 horas do estimulo inflamatório, as tilápias foram 
submetidas à anestesia profunda para eutanásia e necropsia, e assim, obtenção de exsudato e colheita da bexiga natatória para analise da reação inflamatória. Partindo-se desta premissa, o presente estudo demonstrou a participação da insulina na reação inflamatória aguda infecciosa de tilápias do Nilo aloxano-diabéticas por favorecer o acúmulo positivo celular no exsudato, assim como o efeito proliferativo de tecido fibroso e a neovascularização no local inflamado. Tais achados reforçam a hipótese de que a insulina desempenha importante papel na resposta imune inata na reação inflamatória aguda, sendo um importante hormônio pró-inflamatório. Contudo, a tilápia do Nilo demonstrou ser um modelo experimental promissor para estudos e avanços em pesquisas envolvendo o diabetes mellitus.

TERMOS DE INDEXAÇÃO: Insulina, reação inflamatória aguda, tilápia, aloxano-diabéticas, aerocistite, Oreochromis niloticus, ciclídeos, diabetes, hormônios peptídicos, inflamação, Aeromonas hydrophila, clínica.

\section{INTRODUCTION}

In vertebrates, the inflammatory reaction plays an important pathophysiological role in the immune system control, responsible for modulating the initial non-specific defense until the specific immunity is acquired, resulting in the production of pro-inflammatory mediators, leukocyte recruitment, activation of complement system, alteration in the concentration of different plasma proteins, and metabolic modulations (Ashley et al. 2012, Graham et al. 2005).

Numerous studies in mammals had been demonstrated the insulin (ISN) participation in the vascular response during the inflammatory reaction by favoring cell proliferation and migration capacity through endothelial cells, as well as acting in the vascular smooth muscle cells, monocytes, and mediating the expression of thrombotic and pro-fibrotic factors (Hsueh \& Quiñones 2003, Dandona et al. 2009).

The pathophysiology studies of inflammatory reaction in teleosteal fish have been the subject of researches by several authors who have tried to understand the evolution of this response during foreign body type inflammation (Sakabe et al. 2013, Belo et al. 2005, 2012, 2014), granulomatous inflammation (Manrique et al. 2014, 2015) and acute inflammation (Reque et al. 2010, Claudiano et al. 2013, Castro et al. 2014). However, little is known about the effect of INS on the inflammatory response of these animals. Based on this premise, the present study aimed to evaluate the participation of this hormone in the acute inflammatory reaction of Nilo alloxan-diabetic tilapia, submitted to aerocystitis by Aeromonas hydrophila infection, seeking to evaluate the potential of this experimental model for studies and advances involving diabetes mellitus.

\section{MATERIALS AND METHODS}

Nile tilapia (Oreochromis niloticus), mean weight $532 \pm 46.7 \mathrm{~g}$, belonging to the "GIFT" line and masculinized, were randomly distributed in six tanks with 1000L each to performe two treatments: diabetics treated with insulin and diabetics without treatment. This study was approved by the Committee on Ethics in Animal Use (CEUA) of the Faculty of Agrarian and Veterinary Sciences, Unesp, Jaboticabal Campus, under protocol no. 022546/11.
Induction of diabetes. The diabetic effect was induced by alloxan $\left(\right.$ Sigma $\left.^{\circledR}\right)$ administration through intravenous route in the caudal vessel, at a dose of $100 \mathrm{mg} . \mathrm{kg}^{-1}$ of body weight, using as solvent sterile saline solution with $0.65 \%$ (Xu et al. 2004). Thus, one week after the alloxan application, tilapias with glycemic values above $150 \mathrm{mg} \cdot \mathrm{dL}^{-1}$ after 12 hours of fasting were considered diabetic following an established criterion by Xu et al. (2004). Alloxan administration was performed two weeks prior to induction of inflammatory stimulus.

Inflammatory stimulation. For the inflammatory stimulus, $1 \mathrm{~mL}$ of the Aeromonas hydrophila inoculum was injected caudally to the operculum, at the level of lateral line, to reach the anterior swimming bladder, and to induce acute infectious aerocystitis. The concentration of the bacterial inoculum was $7.5 \times 10^{6}$ colony forming units per $\mathrm{mL}$. The isolation and identification was made according to Sebastião et al. (2015).

Insulin therapy. Insulin application (Lantus ${ }^{\circledR}$ ) was performed immediately after bacterial inoculation by subcutaneous route in the ventral region of the left pectoral fin, in a single dose of $10 \mathrm{IU} \cdot \mathrm{kg}^{-1}$ of body weight.

Sampling, processing and analysis of biological material. Eight animals were sampled per group at 6, 24 and 48 hours post-infection (HPI). Deep anesthesia was performed by immersion in benzocaine, followed by necropsy to collect exudate and swimming bladder. For the evaluation of total cell accumulation, $1 \mathrm{~mL}$ of phosphate buffer solution (PBS) was injected at 0.1 molar with pH 7.2 and containing EDTA $0.09 \%$ for the lavage and cell capture in the swim bladder. The total volume of exudate was collected with Pasteur pipette, transferred to falcon tube and kept in refrigeration. The PBS-EDTA-exudate solution was centrifuged at 167xg for five minutes in a clinical centrifuge. The supernatant was discarded, the total pellet was resuspended with the addition of $1 \mathrm{~mL}$ ( $6 \mathrm{HPI})$ and $2 \mathrm{~mL}$ ( 24 and $48 \mathrm{HPI}$ ) PBS and in an aliquot of total cell volume was counted under light microscopy in a Neubauer chamber. The number of cells found was multiplied by the dilution factor (Reque et al. 2010). For the histopathological study, the swimming bladder was removed from each animal and fixed in 4\% paraformaldehyde prepared in PBS (0.1M and pH 7.2). After the procedures of fixation, dehydration, diaphanization and inclusion in paraffin, $5 \mu \mathrm{m}$ thick sections were stained with hematoxylin and eosin (HE).

Statistic. Statistical analysis was performed in a mixed model; the results were tested applying the experimental scheme by subdivided plots, comparing the treatment effect and the interactions between treatment versus time in relation to the groups. The Bartlet test $(\mathrm{P}=>0.05)$ and the Shapiro-Wilk test $(\mathrm{P}=>0.05)$ were used to establish the statistical hypothesis of homocedasticity and normality of the internally standardized residues. Tukey test $(\mathrm{P}<0.05)$ was used for comparisons. All statistical analyzes were processed in SAS ${ }^{\circledR}$ software (Statistical Analysis System), version 9.3.

\section{RESULTS}

In the exudative study (Fig.1), there was a greater presence of inflammatory cells in the group treated with insulin, this effect was notorious in the period of 48 HPI compared to the group without insulin therapy. In the study over time, both groups, with or without insulin therapy had high cell accumulation in the period of $24 \mathrm{HPI}$. The group without insulin therapy presented decrease in the cellular accumulation in the period of $48 \mathrm{HPI}$.

In the histopathological evaluation 6 and 24 HPI (Fig.2), alloxan-diabetic tilapia without insulin therapy showed low-proliferation of fibrous tissue and infiltration of 


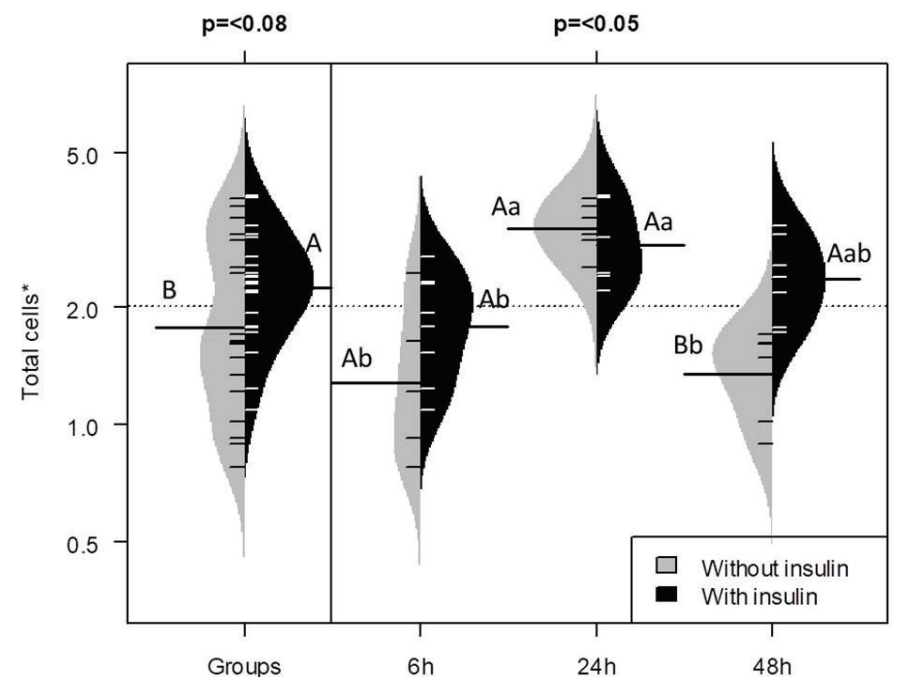

Fig.1. Total cells presented in the exudate of Nile tilapia alloxan-diabetic with acute aerocystitis induced by Aeromonas hydrophila. Fish were sampled six, 24 and 48 hours post-infection (HPI). *Values transformed according to Box and Cox. Comparisons realized by Tukey Test (capital letters compare treatment and lowercase compare different periods). Total number of animals observed $=48$.

inflammatory cells in the swim bladder, as well as serosa thickening. On the other hand, alloxan-diabetic tilapia with insulin therapy showed high proliferation of fibrous tissue, high inflammatory cell infiltration and neovascularization with hyperemia. Acute fibrinosuppurative inflammation was observed in insulin-treated tilapia in 48 HPI. In contrast, alloxan-diabetic tilapia without insulin therapy showed decrease in the of inflammatory cell accumulation 48 HPI.

\section{DISCUSSION}

Decreased fibrous tissue proliferation and low neovascularization at the inflamed site in the diabetic Nile tilapia mimic the same effects observed in diabetic mammals. Since studies have shown that insulin promotes the formation of fibrous tissue, proliferation of endothelial cells and their migration capacity (Hsueh \& Quiñones 2003, Dandona et al. 2009).

However, both groups, with or without insulin therapy, exhibit the same pattern of cellular accumulation response up to the period of $24 \mathrm{HPI}$, such result may be related to the immunomodulatory stimulus of the bacterial lipopolysaccharide (LPS) (Jimenez et al. 2008). According to Munford (2006), LPS play a major role in the activation and amplification of the inflammatory response. As the induction of the pro-inflammatory pathway results from the LPS signal transfer in a complex formed by LPS, LBP, CD14 and TLR4, which initiate a series of intracellular events involving proteins and transcription factors responsible for various genes that encode cytokines, chemokines and adhesion molecules (Cohen 2002).

In confirmation, the LPS inoculum in fish attributed the ability of macrophages to produce interleukin 1 (IL-1) and tumor necrosis factor alpha (TNF- $\alpha$ ), which are responsible for chemotaxis, leukocyte activation and expression of endothelial adhesion molecules (Swain et al. 2008). Thus, LPS plays an important mediator in the process of leukocyte diapedesis

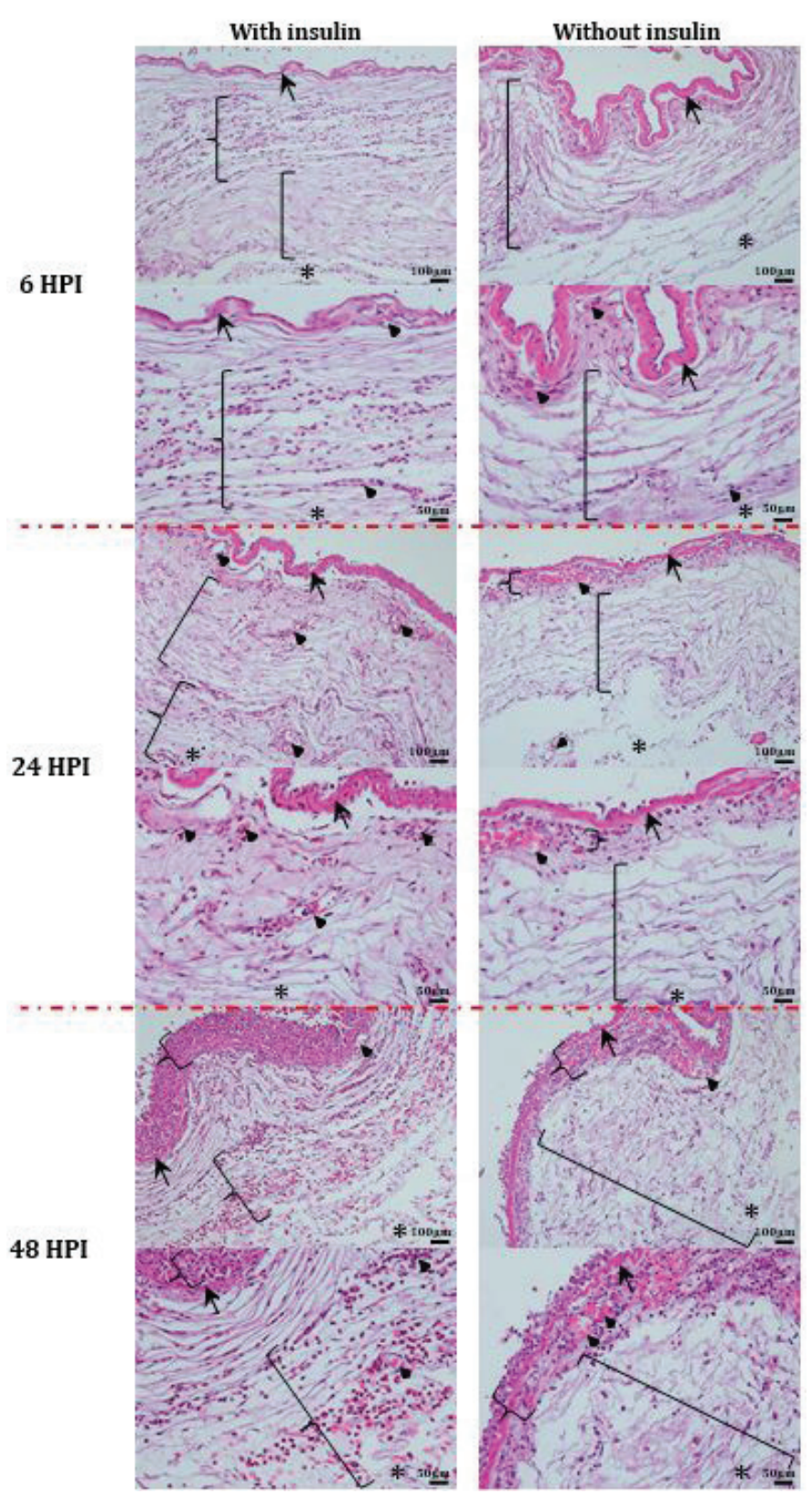

Fig.2. Photomicrographs of the swimming bladder of Nile tilapia alloxan-diabetic with acute aerocystitis induced by Aeromonas hydrophila. Fish were sampled six, 24 and 48 hours post-infection (HPI). Serous membrane (arrow tip), inner side of swim bladder (asterisk), fibrous tissue (bracket), blood vessel (arrow) and infiltrates of inflammatory cells (curly bracket).

in the inflammatory focus in diabetic tilapia with or without insulin therapy $24 \mathrm{HPI}$.

The pro-inflammatory effect of insulin on diabetic tilapia 48 HPI was evident, which presented a fibrinosuppurative inflammatory aspect with high cellular accumulation in the inflammatory focus. In this context, studies have shown that insulin participates in angiogenesis by favoring cell growth, the migratory capacity of endothelial cells, vascular smooth muscle cells and monocytes, mediating the expression of fibrotic factors in response to various stimuli (Clarke \& Dodson 2007). 
Study conducted by Dror et al. (2017) described the insulin participation in the IL-1 production by macrophages. This cytokine stimulate the expression of proteins responsible for adhesion and leukocyte diapedesis, favoring cell growth and differentiation by acting directly on innate immune cells, significantly influencing its functionality and survival, and modulating the activity of lymphocytes during adaptive immune responses (Sims \& Smith 2010). To reinforce the pro-inflammatory stimulus of insulin observed in tilapias $48 \mathrm{HPI}$, in accordance with Agius \& Roberts (2003) and Hodgkinson et al. (2015) macrophages are recruited in large quantity later to the inflamed site in order to maintain the parsimony between the innate and adaptive immune response.

\section{CONCLUSIONS}

The insulin hormone presented a pro-inflammatory effect in Nile tilapia alloxan-diabetic submitted to acute aerocystitis by Aeromonas hydrophila infection, because it favors the accumulation of inflammatory cells in the exudate and results in a proliferative effect of fibrous tissue with neovascularization in the inflamed site.

Such results associated with the success of insulin therapy in tilapias demonstrated the potential of this experimental model for studies and advances in researches involving diabetes mellitus.

Acknowledgements.- The authors are grateful for the financial support from Fapesp, Research Foundation from São Paulo State, (Processes 2011/169459 and 2012/12256-7).

\section{REFERENCES}

Agius C. \& Roberts R.J. 2003. Melano-macrophage centres and their role in fish pathology. J. Fish Dis. 26(9):499-509. <http://dx.doi. org/10.1046/j.1365-2761.2003.00485.x> <PMid:14575368>

Ashley N.T., Weil Z.M. \& Nelson R.J. 2012. Inflammation: mechanisms, costs, and natural variation. Annu. Rev. Ecol. Evol. Syst. 43(1):385-406. <http:// dx.doi.org/10.1146/annurev-ecolsys-040212-092530>

Belo M.A.A., Schalch S.H.C., Moraes F.R., Soares V.E., Otoboni A.M. \& Moraes J.E.R. 2005. Effect of dietary supplementation with vitamin E and stoking density on macrophage recruitment and giant cell formation in the teleost fish, Piaractus mesopotamicus. J. Comp. Pathol. 133(2/3):146-154.<http:// dx.doi.org/10.1016/j.jcpa.2005.04.004> <PMid:16033696>

Belo M.A.A., Moraes J.R.E., Soares V.E., Martins M.L., Brum C.D. \& Moraes F.R. 2012. Vitamin $C$ and endogenous cortisol in foreign-body inflammatory response in pacus. Pesq. Agropec. Bras. 47(7):1015-1021. <http://dx.doi. org/10.1590/S0100-204X2012000700019>

Belo M.A.A., Moraes F.R., Yoshida L., Prado E.J.R., Moraes J.R.E., Soares V.E. \& Moraes F.R. 2014. Deleterious effects of low level of vitamin E and high stocking density on the hematology response of pacus, during chronic inflammatory reaction. Aquaculture 422:124-128. <http://dx.doi. org/10.1016/j.aquaculture.2013.12.013>

Castro M.P., Claudiano G.S., Petrillo T.R., Shimada M.T., Belo M.A., MarzocchiMachado C.M., Moraes J.R., Manrique G.W. \& Moraes F.R. 2014. Acute aerocystitis in Nile tilapia bred in net cages and supplemented with chromium carbochelate and Saccharomyces cerevisiae. Fish Shellfish Immunol. 36(1):284-290. <http://dx.doi.org/10.1016/j.fsi.2013.11.012> <PMid:24309138>

Clarke M. \& Dodson P.M. 2007. PKC inhibition and diabetic microvascular complications. Best Pract. Res. Clin. Endocrinol. Metabol. 21(4):573-586. <http://dx.doi.org/10.1016/j.beem.2007.09.007> <PMid:18054736>

Claudiano G.S., Petrillo T.R., Manrique W.G., Castro M.P., Loureiro B.A., Marcusso P.F., Belo M.A.A., Moraes J.R.E. \& Moraes F.R. 2013. Acute aerocystitis in Piaractus mesopotamicus: participation of eicosanoids and pro-inflammatory cytockines. Fish Shellfish Immunol. 34(5):1057-1062. <http://dx.doi. org/10.1016/j.fsi.2013.01.006><PMid:23370015>

Cohen J. 2002. The immuno pathogenesis of sepsis. Nature 420(19):885-891. <http://dx.doi.org/10.1038/nature01326> <PMid:12490963>

Dandona P., Chaudhuri A., Ghanim H. \& Mohanty P. 2009. Insulin as an antiinflammatory and antiatherogenic modulator. J. Am. Coll. Cardiol. 53(Suppl.5):S14-S20. <http://dx.doi.org/10.1016/j.jacc.2008.10.038> <PMid:19179212>

Dror E., Dalmas E., Meier D.T., Wueest S., Thévenet J., Thienel C., Timper K., Nordmann T.M., Traub S., Schulze F., Item F., Vallois D., Pattou F., KerrConte J., Lavallard V., Berney T., Thorens B., Konrad D., Böni-Schnetzler M. \& Donath M.Y. 2017. Postprandial macrophage-derived IL-1 [beta] stimulates insulin, and both synergistically promote glucose disposal and inflammation. Nat. Immunol. 18(3):283-292.<http://dx.doi.org/10.1038/ ni.3659><PMid:28092375>

Graham A.L., Allen J.E. \& Read A.F. 2005. Evolutionary causes and consequences of immunopathology. Annu. Rev. Ecol. Evol. Syst. 36(1):373-397. <http:// dx.doi.org/10.1146/annurev.ecolsys.36.102003.152622>

Hodgkinson J.W., Grayfer L. \& Belosevic M. 2015. Biology of bony fish macrophages. Biology 4(4):881-906. <http://dx.doi.org/10.3390/ biology4040881><PMid:26633534>

Hsueh W.A. \& Quiñones M.J. 2003. Role of endothelial dysfunction in insulin resistance. Am. J. Cardiol. 92(4):10-17.<http://dx.doi.org/10.1016/S00029149(03)00611-8> <PMid:12957322>

Jimenez N., Canals R., Salo M.T., Vilches S., Merino S. \& Tomás J.M. 2008. The Aeromonas hydrophila $\mathrm{wb}^{*} 034$ gene cluster: genetics and temperature regulation. J. Bacteriol. 190(12):4198-4209. <http://dx.doi.org/10.1128/ JB.00153-08> <PMid:18408022>

Manrique W.G., Claudiano G.S., Petrillo T.R., Castro M.P., Figueiredo M.A.P., Belo M.A.A., Moraes J.R.E. \& Moraes F.R. 2014. Response of splenic melanomacrophage centers of Oreochromis niloticus (Linnaeus, 1758) to inflammatory stimuli by BCG and foreign bodies. J. Appl. Ichthyol. 30(5):1001-1006. <http://dx.doi.org/10.1111/jai.12445>

Manrique W.G., Silva C., Castro M.P., Petrillo T.R., Figueiredo M.P., Belo M.A.A., Moraes J.R.E. \& Moraes F.R. 2015. Expresion of cellular components in granulomatous inflammatory response in Piaractus mesopotamicus model. PLos One 10(3):e0121625. <http://dx.doi.org/10.1371/journal. pone.0121625><PMid:25811875>

Munford R.S. 2006. Severe sepsis and septic shock: the role of gram-negative bacteremia. Annu. Rev. Pathol. Mech. Dis. 1:467-496. <PMid:18039123>

Reque V.R., Moraes J.E.R., Belo M.A.A. \& Moraes F.R. 2010. Inflammation induced by inactivated Aeromonas hydrophila in Nile tilapias fed diets supplemented with Saccharomyces cerevisiae. Aquaculture 300(1/4):3742. <http://dx.doi.org/10.1016/j.aquaculture.2009.12.014>

Sakabe R., Moraes F.R., Belo M.A.A., Pilarski F. \& Moraes J.R.E. 2013. Kinetics of chronic inflammation in Nile tilapia fed $\mathrm{n} 3$ and $\mathrm{n} 6$ essential fatty acids. Pesq. Agropec. Bras. 48(3):313-319. <http://dx.doi.org/10.1590/S0100204X2013000300010>

Sebastião F.A., Furlan L.R., Hashimoto D.T. \& Pilarski F. 2015. Identification of bacterial fish pathogens in Brazil by direct colony PCR and 16S rRNA gene sequencing. Adv. Microbiol. 5(06):409-424. <http://dx.doi.org/10.4236/ aim.2015.56042>

Sims J.E. \& Smith D.E. 2010. The IL-1 family: regulators of immunity. Nat. Rev. Immunol. 10(2):89-102. <http://dx.doi.org/10.1038/nri2691> <PMid:20081871>

Swain P., Nayak S.K., Nanda P.K. \& Dash S. 2008. Biological effects of bacterial lipopolysaccharide (endotoxin) in fish: a review. Fish Shellfish Immunol. 25(3):191-201. <http://dx.doi.org/10.1016/j.fsi.2008.04.009> <PMid:18603445>

Xu B.Y., Morrison C.M., Yang H. \& Wright Jr J.R. 2004. Tilapia islet grafts are highly alloxan-resistant. Gen. Comp. Endocrinol. 137(2):132-140. <http:// dx.doi.org/10.1016/j.ygcen.2004.02.017><PMid:15158125> 